\title{
The Last Northern Cod
}

\section{Thomas R. McGuire}

The collapse of the northern cod stocks (Gadus morhua) off Newfoundland resulted in an indefinite moratorium that has affected 40,000 fishers and fish plant workers in Atlantic Canada. This poses theoretical and methodological challenges for the emergent field of political ecology. A cottage industry of postmortems has arisen since the collapse, and we are very close to 20-20 hindsight about the causes of the catastrophe. Thus it is possible to ask whether a rigorous application of a political ecology could have foreseen the event. I will argue to the contrary. Political ecology, as it is now developing, has privileged its political economic ancestors at the expense of its cultural ecologic ones. And in its ideological concern for the environmental consequences of capitalist extraction and production, it has left little scope for the examination of quite reasonable people doing quite reasonable things. ${ }^{1}$ Of no mean consequence to the story were technologically innovative people.

Political ecology is emerging from the study of environmental destruction in the Third World. Michael Painter has provided a useful enumeration of the now familiar elements posed by Marianne Schmink and Charles Woods (1987) for such study:

(1) the nature of production in a region, and, in particular, the degree to which it is oriented toward simple reproduction or capital accumulation; (2) the class structure of the society...and the lines of conflict over access to productive resources; (3) the extent and kinds of market relations in which producers are involved...; (4) the role of the state in defining and executing policies that favor the interests of certain classes or resource users over others; (5) international interests...that may support particular patterns of resource use; and (6) the ideology that orients resource use...and what groups benefit from that ideology (M.Painter 1995:8).

My preference is for an approach that begins precisely where Julian Steward began -the nexus of relationships, as Painter phrases it, "between the immediate users of a technology and the environment" (1995:4) -- and goes on, as Andrew Vayda proposed some years ago (A.Vayda 1983; 1988), to progressively contextualize such interactions. Schmink and Woods, for their part, acknowledge the methodological utility of Vayda's approach, but only if the contextualizing process is guided and organized by a "political economy perspective" such as the principles enumerated above (M.Schmink and C.Woods 1987:53). My argument is that such guiding principles would not have revealed the cause of the collapse of the northern cod and would not have guided us to the context of that collapse.

1. I take a cue here from the historian Donald Pisani's characterization of some environmental history of the American west, written from a political economic perspective: "[Stanley Roland] Davison and [Donald] Worster, in particular, reduce complicated history to little more than a morality play. With few exceptions, their "players" are one-dimensional: fools, innocents, and victims pitted against self-serving technocrats, politicians, and predatory capitalists. Occasionally a hero, such as [John Wesley] Powell, struts across the stage, but believable men -- let alone good ones -- are hard to find" 1992:332). 
I begin by reviewing what we think we know now about the rise and fall of the cod fishery off Newfoundland which, as I suggested above, can be arguably interpreted as a compilation of reasonable acts by reasonable people. Then I briefly examine two indigenous scholarships that roughly bracket the collapse: the political economic tradition in Atlantic Canada prior to the collapse, and a revived cultural ecology after it. Finally, I offer some suggestions for what a political ecology might attend to.

\section{The Last Cod}

In 1977, Canada declared exclusive control over its coastal waters out to 200 miles. Up until then, groundfish stocks had been managed by the rather hapless International Commission for the Northwest Atlantic Fisheries (ICNAF), empowered to allocate, but not enforce, country quotas for foreign distant-water fleets. By the 1960s, factory freezer trawlers from France, Germany, Poland, the Soviet Union, Spain, Portugal, Iceland, Norway, and the United Kingdom were competing with Canadian fleets and a precarious inshore fishery in Newfoundland for groundfish stocks. Following the wisdom of the time, ICNAF set total allowable catches (TACs) at a level equal to "maximum sustainable yield" $\left(\mathrm{F}_{\mathrm{msy}}\right)$, which, as it turned out, was well in excess of what the stocks could bear, and indeed, above the actual catches of the deep-water fleets by the mid-1970s. Catches in ICNAF's northern cod management zones (2J3KL) off eastern Newfoundland declined from a peak of 800,000 metric tons in the late 1960 s to 214,000 tons by 1976 . By then, it was abundantly clear that the northern cod had been overfished, and that Canada, acquiring control of the grounds, had to undertake a rebuilding process (see Figure 1).

In assuming fisheries management responsibilities for the extended zone, the federal Department of Fisheries and Oceans (DFO) approached the rebuilding process with caution. The concept of total allowable catch remained the key management tactic, but a new and more modest fishing mortality target, $\mathrm{F}_{0.1}$, replaced $\mathrm{F}_{\mathrm{msy}}$ as the standard for calculating quotas. Under $\mathrm{F}_{0.1}$, roughly 18 percent of exploitable cod biomass would be harvested annually, providing, it was believed, "a buffer against stock assessment errors and enforcement deficiencies" (W.H.Lear and L.S.Parsons 1993:66; cf. also D.H.Steele et al. 1992) and a rather rapid buildup of stocks.

Newfoundland's fishery, devastated by the biological and economic crisis of the mid1970s, had to be rebuilt as well, and "from the coast out": inshore fishers and plant workers would be favored. Indeed, there was a "rapid expansion of the inshore fishery in the late 1970s which saw an increase of 8,000 new fishermen and 4,600 vessels" (R.Matthews and J.Phyne 1988:161).

In 1979 Fisheries Minister McGrath declared:

For these people, for the people working in processing plants, for their families and the communities in which they live, the right and the ability to reap this harvest is indispensable, because they have a special, a very special relationship to these stocks (in W.H.Lear and L.S.Parsons 1993:66).

In terms of fish, the inshore sector received an allocation of 110,000 tons in 1980, of a total allowable catch of 180,000 tons. Subsequently, through the decade, the inshore share of successive TACs would be reduced to less than half as inshore fishers found it increasingly difficult to catch cod. As the decade began, the inshore sector was comprised of 18,000 vessels under 35 feet, 1,400 "longliners" of 35 to 65 feet, and some 35,000 
The Last Northern Cod

fishers, about half of whom were considered to be "full-time" under an individual licensing system which evolved, in 1980, into a means of limiting entry into the fishery.

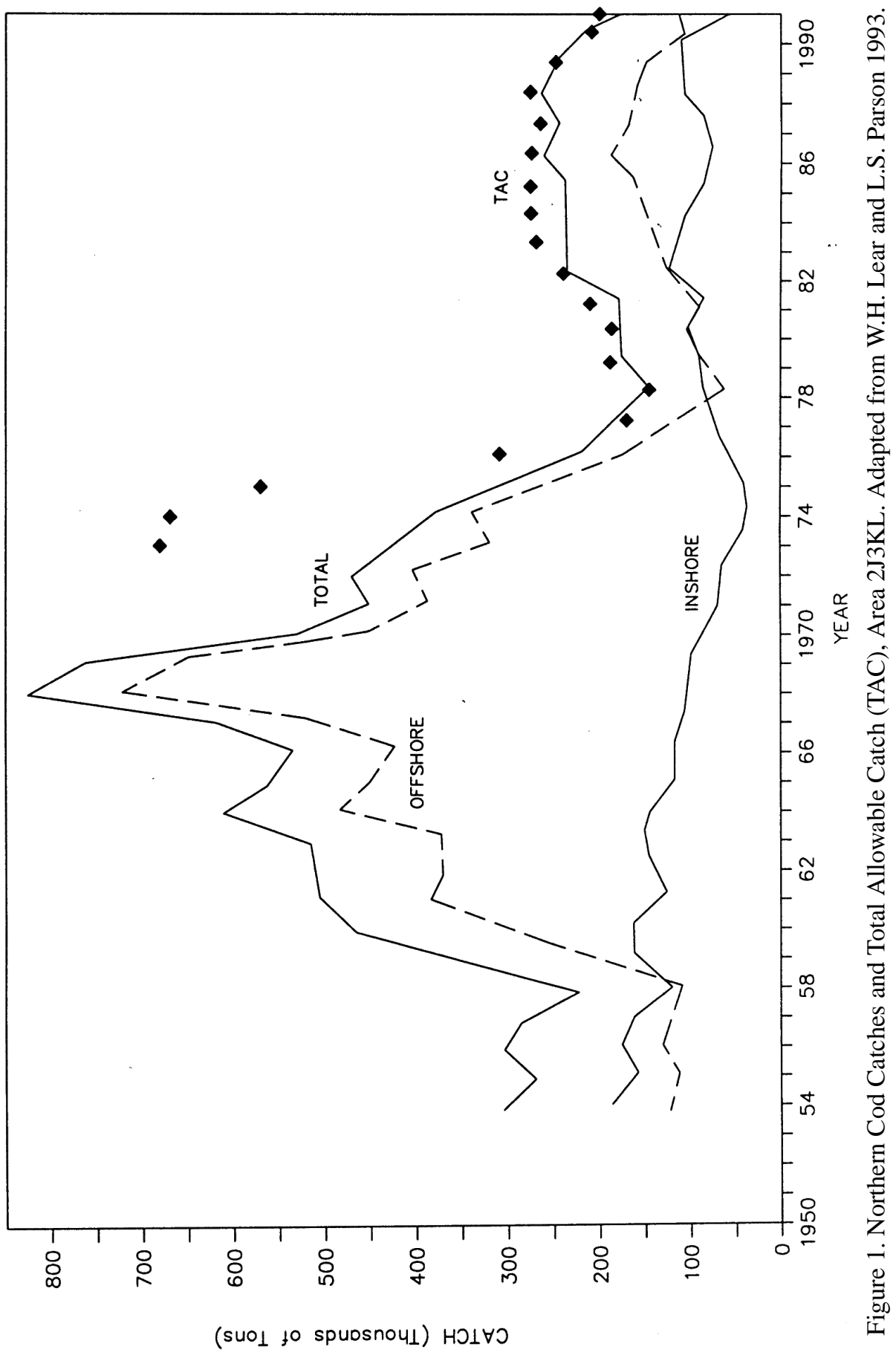


The longliner fleet was introduced, with government financial incentives, in the 1950s and 1960s as an "intermediate" technology to free inshore fishers of the constraints posed by traditional cod trap technology. Traps, since the 1880s, had been employed to capture the summer inshore migration of cod, feeding on schools of capelin. Although an effective technology, the trap necessarily limited the fishing season and coastal mobility of fishers. Thus larger, decked vessels using gillnets or ottar trawls were encouraged to enhance fishing capacity, prolong the season, and provide additional product for plant workers to process. Following the Canadianization of the waters in 1977, longliner fleets were expanded with government assistance programs, with the additional supposition that the longliner fleets, independent of the vertically integrated offshore firms, would generate local foci of capital accumulation (R.Rogers 1995:73). This soon proved not to be true, as an economic crisis in the fishery in the early 1980s, due in large measure to global monetary conditions and declining U.S. markets, left many longline owners in grave financial conditions.

Nonetheless, the introduction of this technology has had a resultant economic differentiation in Newfoundland's outports, as we shall see. But individual owners of longliners remain, according to sociologist Peter Sinclair's (1985) analysis, "petty capitalists," residing along side the domestic commodity producers who are unable to purchase longliners. Federal regulations also afforded longliners some protection from competition: vessels larger than 65 feet were precluded from fishing within 12 miles of the coast.

Offshore there are roughly 90 deep-sea stern- and side-trawlers, 100 to 200 feet in length, operating out of a dozen ice-free harbors on the south and east coasts of Newfoundland. They were operated by vertically integrated processing concerns, and were required to process their catch in Newfoundland plants. Each company was given an enterprise allocation -- a percentage of the offshore TAC -- and in theory can pace its fishing operations throughout the year to make efficient use of its processing capacity and provide year-long employment. By 1990, there were some 27,000 fish-plant workers.

For much of the 1980s, fisheries and government interests in Newfoundland actively resisted the introduction of massive factory freezer trawlers, those such as scoured the North Atlantic up to 1977 and had the potential to reduce on-shore processing work. Fisheries Minister Crosbie granted one license to National Sea, the large Nova Scotiabased processor, in 1987 and perhaps, as some feared, this action would have opened the floodgates to a technology most people disdained. The moratorium intervened.

I would suggest that there is little in Newfoundland's vision of the fishery in 1977 that was grossly unreasonable or radically unjust, nor much that portended the catastrophe of 1992. Inshore and offshore capacity, after an expansion in the late 1970s to reap the coming bonanza of a rejuvenated stock, and the curtailments resulting from the economic crisis of the early 1980s, has subsequently -- ostensibly -- reached relative stability. Total allowable catches were adjusted yearly by DFO scientists to reflect -- presumably -- a cautious level of fishing mortality. And inshore fishermen were encouraged, in contrast to the forced and despised resettlement schemes of the 1960s, to remain in scattered outport communities, buoyed by policies which attempted to decentralize processing facilities and provide unemployment insurance when alternative income was unavailable. Why, then, the commercial extinction of the northern cod in 1992 ?

The early postmortems marshalled the usual suspects: water temperature changes which forced the cod out of Canadian waters, the predation of large and growing seal populations on cod and cod's prey, continued foreign fishing on the Nose and Tail of the 
Grand Banks outside Canada's 200-mile zone, and, finally, overfishing. Only the last has survived the scrutiny of hindsight, but the answer takes some unexpected twists. It begins with real people doing real things, as Andrew Vayda (1983; 1988) might say.

Commercial catch per unit effort (CPUE) bedeviled the cod. Routinely collected in fisheries, in this case primarily from the 90 or so offshore trawlers, CPUE data are used to calibrate and fine-tune stock assessments from which Total Allowable Catch is set. It seemed reasonable to DFO scientists (and indeed, most stock assessors make the same assumption) that catch rates and total stock abundance are related in a linear fashion. For the northern cod, it is now known that they were not (see Figure 2).

In some fisheries, where managers lack funds to conduct independent research surveys, CPUE may be the only available index of stock abundance. In Canada, DFO did have funds in the 1980s to carry out such surveys, but the results of the two data sets diverged markedly. Ray Hilborn and Carl Walters succinctly define the conundrum:

The problem facing the scientists was the discrepancy between the surveys, which indicated that the stocks had grown very little since 1978 (and therefore the fishing mortality rate was too high), and the CPUE which indicated that the stock was about three times higher in the late 1980s than it had been 10 years earlier (1992:534).

In retrospect, it is now suspected that three processes were at work here. First, in the euphoric though cautious optimism after Canada declared its 200-mile exclusive zone, Canadian deep-water trawlers were upgraded with technology for finding and harvesting fish, even if the actual number of vessels was held in check. Second, skippers were encouraged to fish in areas that had heretofore been the province of the foreign distant water fleets, and they quite rapidly, apparently, learned those grounds. Third, there was an apparent increase in cod stock concentrations as these stocks declined in the 1980s, increasing their "catchability." Together, these processes interacted to distort the interpretation of catch per unit effort. High trawler catch rates coincided with declining stocks because fishers were discovering, through the decade, where to find the last northern cod (cf. J.Hutchings and R.Myers 1994; J.Hutchings et al. 1997; C.Walters and J.Maguire 1996; for a popular treatment of cod history, see M.Kurlansky 1997).

Within the inshore sector, technological advances were going on apace, although these were not documented effectively until the decline. Hutchings and Myers summarize some of the evidence now being marshalled by sociologists from Memorial University of Newfoundland:

It is clear that the ability of inshore fishers to catch fish has increased dramatically with time, particularly during the 1980 s... For example, echo sounders can permit the employment of greater number of cod traps per fisher because of the avoidance of hauling empty traps. Sounders also reduce the time handline fishers spend on locating cod. Throughout the 1980s, there was increased use of "Japanese" cod traps whose design allows for reduced escapement of fish and permits their placement in areas unsuitable for regular traps... Advanced navigation equipment such as Loran C enables fishers to record electronically the location of large fish assemblages, sites of previously large catches, and the precise orientation of gillnet sets...(1994:2141).

I will revisit this body of knowledge below, but let me return to the story. Without taking account of increasing efficiency in the fishery, DFO scientists resolved the discrepancies between offshore commercial catch and research survey indices essentially by averaging the two. This resulted in a substantial overestimation of stock abundance, TACs which were excessive, and an actual fishing mortality that exceeded the target of 
$\mathrm{F}_{0.1}[\mathrm{~F}=.18]$ twofold from 1978 to 1983 and threefold from 1984 to 1989 (J.Hutchings and R.Myers 1994:2142).

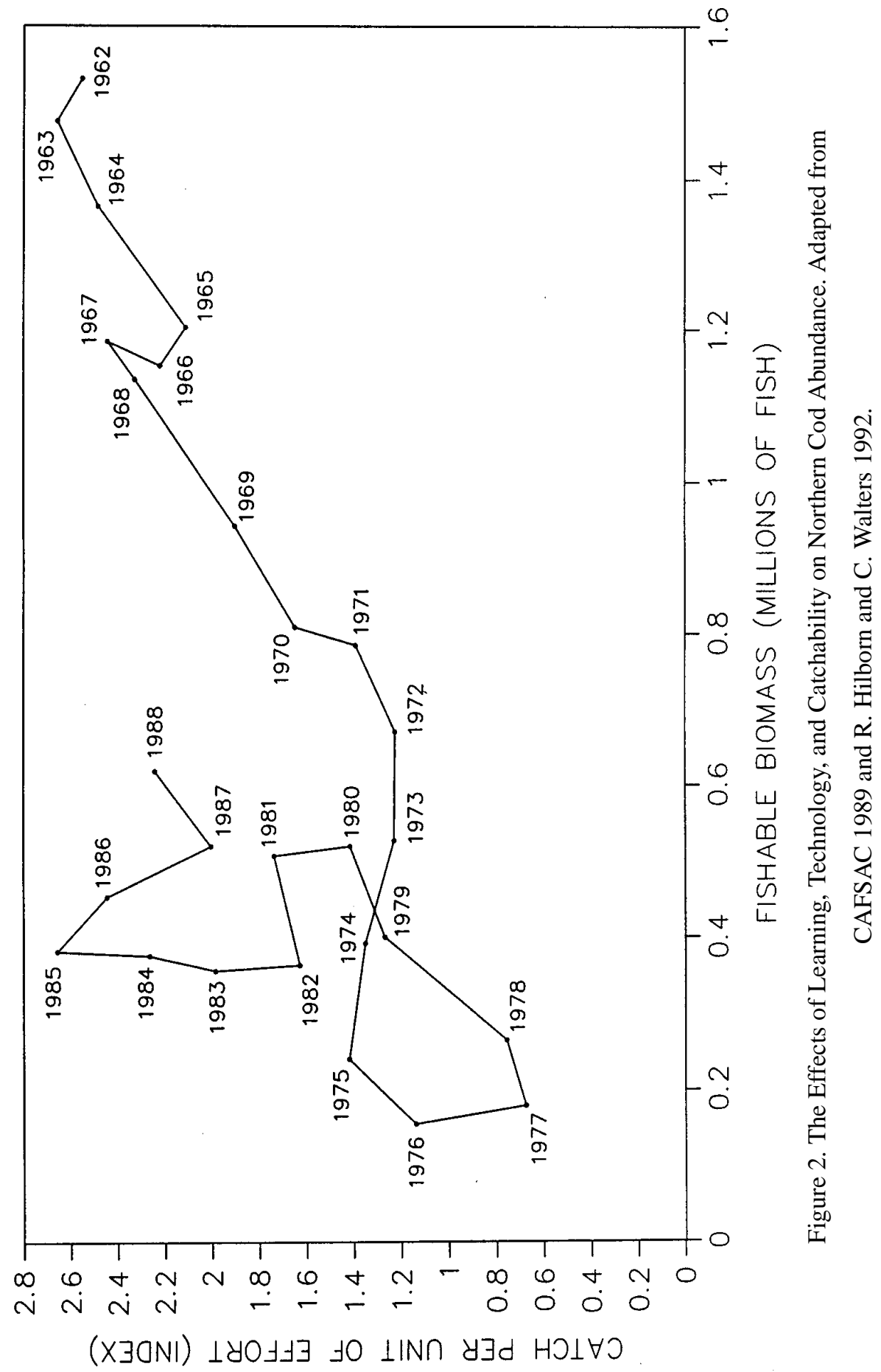


Retrospectives have highlighted the dissidents in the stock assessment fraternity. One of these was DFO's own Dr. George Winters, who raised methodological questions regarding the June assessment of 1986 and implicated offshore overexploitation in the decline of inshore catches. That DFO failed to heed these warnings and reduce TACs may be due as much to the agency's research surveys in the fall of 1986 -- showing an extremely high, and entirely preposterous, abundance of cod -- as to agency complicity with industry (cf. J. Hutchings et al. 1997:1202). ${ }^{2}$

Few of those now doing the postmortems predict a recovery. Indeed, two DFO scientists give a dire warning:

the extremely low abundance of northern cod in the 1990s raises justified concern that increased vulnerability to both fishing (within and without the 200-mile limit) and naturally occurring environmental variation may significantly increase the probability of extinction of this stock (J.Hutchings and R.Myers 1994:2143).

\section{Political Economy in Atlantic Canada}

In the 1970s and 1980s, a very rich scholarship in political economy developed in Atlantic Canada, much of it an effort to interject and fine-tune a class analysis of the fisheries. The intellectual protagonist for this work was the economic historian Harold A. Innis, whose monumental tomes, The Fur Trade in Canada: An Introduction to Canadian Economic History (1930) and The Cod Fisheries: The History of an International Economy (1940) defined the "staples theory" of Canadian development. A famous passage from The Fur Trade, later read by some scholars as an incipient dependency theory, states:

The economic history of Canada has been dominated by the discrepancy between the centre and the margin of western civilization... agriculture, industry, transportation, trade, finance and governmental activities tend to become subordinate to the production of the staple for a more highly specialized manufacturing community (H.Innis 1956:385)

The radical critique of Innis, however, considered his driving concern for environment and technology (including some rather cursory observations on the life histories of beavers and codfish) as "commodity fetishism," and thus Innis himself as little more than a classical, not Marxist, political economist. David McNally sets the alternative agenda:

2. In their well-known essay, "Judgment under Uncertainty: Heuristics and Biases," first published in 1974, Amos Tversky and Daniel Kahneman illustrate the process of "insensitivity to predictability":

People are sometimes called upon to make such numerical predictions as the future value of a stock, the demand for a commodity, or the outcome of a football game. Such predictions are often made by representativeness. For example, suppose one is given a description of a company and is asked to predict its future profit. If the description of the company is very favorable, a very high profit will appear most representative of that description; if the description is mediocre, a mediocre performance will appear most representative. The degree to which the description is favorable is unaffected by the reliability of the description or by the degree to which it permits accurate prediction. Hence, if people predict solely in terms of the favorableness of the description, their predictions will be insensitive to the reliability of the evidence and to the expected accuracy of the prediction (1982:8). 
For Marx... capitalist production is fundamentally the production and reproduction of the capitalist social relationship -- the dialectical relation between wage-labour and capital. Once production is viewed simply as a technico-material process -- as in Smith, Ricardo, Veblen, Innis, etc. -- then the dynamics of social production are reduced to those of technological change (1981:45).

In his minor classic on the northwest Newfoundland fisheries, From Traps to Draggers (1985), Peter Sinclair is concerned with technological change, but his focus is on the nexus of technology and class, not technology and fish. His resulting analysis is an internal critique of structural Marxism. Domestic commodity production -- fishers using small boats, family labor, and trap and handline/dragger technology -- have survived and even expanded in numbers. In part this is due to state intervention in the form of unemployment insurance and the occasional availability of wage-labor jobs in processing plants. But he also notes that:

\begin{abstract}
...the uncertain, seasonal and small-scale nature of inshore fishing leaves domestic commodity producers free from the direct competition of large-scale capitalists for whom this type of investment is unattractive...Furthermore, fish companies prefer the quality and size of dragger-caught fish (P.Sinclair 1985:144).
\end{abstract}

State intervention also played a role in first encouraging, then dampening, the expansion of the longline/dragger fleets. By providing loans and subsidies, federal and provincial governments enabled local residents to acquire vessels and gear and generated, in Sinclair's terms, an incipient class of petty capitalist producers, with roots in traditional communities but with increasing interest in capital accumulation and, in the 1980s, increasing debts. Sinclair notes the technological efficiency of the dragger: "skippers can count on the pinpoint accuracy of a Loran C navigation aid, radar, echo sounder, VHF/CB radio and perhaps an automatic pilot" (1985:84). The strength of his analysis, however, is of the growing social tensions created by economic differentiation and frequent militancy of fishers and plant workers, joined in the Newfoundland Fishermen, Food and Allied Workers' Union. In short, these are precisely the issues of class and power which went undeveloped in Harold Innis' staples approach to Canadian history. But, as Sinclair would subsequently acknowledge in a footnote to a postmortem on the collapse of the cod, "An example of research that would have benefited from more attention to ecology is P.R. Sinclair, From Traps to Draggers" (J.Maguire et al. 1995:150).

Anthony Davis and Victor Thiessen do raise ecological concerns in companion articles in 1986. But alas they are raised more as self-evident truths than as a point for analytical departure and, perhaps, an explicit warning to resource managers and their scientific advisors:

While the offshore sector may be technically sophisticated, this has been achieved at the expense of much greater debt and cost burdens than those seen in the inshore sector. Moreover, in order to satisfy these financial requirements and generate income, the offshore sector must land large volumes of fish relative to the volumes required by inshore fishermen. This presupposes the existence of fish stocks sufficient to support such efforts (A.Davis and V.Thiessen 1986:209; cf. also V.Thiessen and A.Davis 1986).

Another pair of Canadian political economists to broach ecological issues in the 1980s was Ralph Matthews and John Phyne (R.Matthews and J.Phyne 1988; cf. R.Matthews 1993). Part of their effort went to fine-tuning Sinclair's class analysis ${ }^{3}$ but the focus was a 
critique of the Department of Fisheries and Ocean's acceptance of limited entry as a solution to open access problems in the fishery. Such policies, they contend, simply foster the private accumulation of capital; they do not enhance resource management (R.Matthews and J.Phyne 1988:162).

Consonant with the growing literature on local management, Matthews and Phyne contend that instead of limited entry licensing, what was needed was government involvement to maintain the integrity of "traditional cooperative measures for policing that common property" (1988:167). Describing the traditional practice of drawing for a limited number of cod trap berths, they conclude that "traditional practices ensure that resource depletion due to over-fishing does not occur" (1988:167). The assertion, of course, raises the familiar problematic that all but scuttled an earlier cultural ecology: it is not demonstrated.

Much of the political economic scholarship in Atlantic Canada provided a trenchant and necessary critique of Canadian fisheries policy and development. And, by examining issues of class and power, it filled the lacunae in Harold Innis' staples theory. But I would suggest that it did not capture the magnitude of the stock crisis as it unfolded surreptitiously through the 1980s. Because there is now a developing body of retrospective ecological understanding, we might ask whether lines of analysis rooted in the nexus of environment and technology might have fared better.

\section{Cultural Ecology in Atlantic Canada}

Coincident with the drastic stock declines of the late 1980s, there was a resurgence of interest among some of Atlantic Canada's social scientists in fishers' local knowledge of resources. One noteworthy effort is the ongoing research of Barbara Neis and Larry Felt (B.Neis 1992; L.Felt 1994; L.Felt and B.Neis 1996) from Memorial University to record this local knowledge and endeavor to interject it into fisheries management. Using archival and anthropological sources (notably from the 1960s and 1970s) and field interviews with inshore fishers in the 1990s, they have underscored what many inshore fishers were claiming in the 1980s: the stock was in trouble. And Alan Christopher Finlayson analyzes why such local wisdom of inshore fishermen indeed played little role in the stock assessment process through the 1980s.

Finlayson's well-regarded book, Fishing for Truth: A Sociological Analysis of Northern Cod Stock Assessments From 1977-1990 (1994), prepared as a master's thesis at Memorial, is a dialogue with key actors in the assessment process through the decade. Jake Rice, head of the cod assessment program at DFO, is given the opportunity to respond to Finlayson's critique of DFO's “interpretative flexibility" regarding the contradictory data coming from the research surveys and the offshore commercial catches, as well as to DFO's unwillingness or failure to account for equally contradictory signals coming from the inshore sector. Rice recounts the problem:

3. They develop Sinclair's observation that fisheries policy creates privileged groups:

...it should also be emphasized that this distinction does support the economic and class interests of all full-time fishermen, whether they be small capitalists, independent commodity producers, or the sharemen who work as wage labour. It is this coincidence of class interests that provides the basis for widespread support for licensing among full-time fishermen and by those part-time fishermen who aspire to be full-time fishermen (R.Matthews and J.Phyne 1988:171). 
“The fishermen's inshore catches were completely incompatible with what we now view as the trajectory. The stock built until around ' 84 , stayed stable to ' 87 and then dropped probably $15-20$ percent with the really poor recruiting year-classes we've had coming in. So it went up, went flat, and now it's down. The inshore went up, dropped a lot, was down for two years, went up and has been climbing slowly ever since. This year [1990] the projections are that it's probably going to be the best year in 20 years for the inshore. So the inshore catches are not tracking what we calculate as the total stock trajectory" (in A.Finlayson 1994:116).

Finlayson's primary critique is that DFO chose to ignore signs from the inshore sector that stocks were in trouble because of its institutional commitment to hard science, and thus to the abundant and readily available data sets coming in from the offshore sector. Hence, to Finlayson, "the inshore fishery is not seen by most scientists as a source of valid knowledge" (1994:105). Rice's response is that Finlayson confounds validity with tractability:

"I know of no fisheries scientist who feels the inshore fishery is not valid. The knowledge is not tractable to our tools, however...and is therefore prone to be underutilized..." (quoted in A.Finlayson 1994:105).

Finlayson offers little resolution to the problem of assimilating vastly different data sources: those of the inshore, where the diverse technologies of traps, gillnets, and handlines do indeed make the standardization of a catch per unit effort virtually intractable; and those from the offshore.

Neis and Felt, in their efforts to understand local knowledge of fisheries and ecosystems, argue that such calibration is not necessary. There are abundant clues, in this fund of knowledge, that would have or should have been read as danger signals in the 1980s. Neis (1992:165) catalogs these: smaller fish being caught with traps and handlines, intensified fishing effort, shorter seasons, increased competition for space. Two of her informants from Petty Harbour found themselves forced to increase the number of traps they worked:

“...Started off one, now we got four. Even though we were increasing our gear the fish were getting much smaller. Fish wasn't half the size the last few years as they had been years before that. We had to catch twice as much fish for the same amount of weight. We even had to change the twine size in our traps. One time we used to use 8 inch twine in the side of the trap and the drawing twine would be 3 and 1/2, now we got to put 5 inch or 4 inch in the side to stop a lot of those smaller fish from going out through the side of the trap. but, since the early 1980s, I'd say, we noticed the fish getting much smaller" (David Hearn, quoted in B.Neis 1992:163).

Neis observes as well that declining catches and technological changes in processing plants "have discouraged fishers from leaving any fish because they can now sell smaller fish and because, much more than in the past, they cannot be assured of future catches" (1992:161). And her research documented the increasing use of "Japanese" traps, mentioned previously:

Japanese traps can be placed with less risk in berths with rougher bottoms and where, owing to tides, it was difficult to hold fish in the past. They have a smaller mesh, are easier to haul, and have a roof; it is more difficult for the fish to find their way out again. Japanese traps opened up new areas to the trap fishery but by the late 1980s, even these areas were filled (B.Neis 1992:164). 
Although Neis provides a compelling account of the technological response to declining resources, she stopped short of an analysis of the reciprocal influence of inshore technology on cod stocks: the harvesting of young fish. Speaking of Icelandic stocks, the biologist D. J. Garrod poses the problem:

...the average age of first capture generally remains well below the optimum. This reduces the yield per recruit but, more seriously, it reduces the spawning stock, leading to concern for the maintenance of recruitment (1988:206).

I suggested at the outset that near 20-20 hindsight had developed after the collapse of the cod. Perhaps this isn't so. The effects of traps on stocks have remained largely unresearched. Barbara Neis' informants to the contrary -- they recall historically catching large cod in traps -- Jake Rice contends that:

The trap fishery has always caught almost completely immature fish -- too young and too small to spawn. (Not just in the 1980s with the 'mismanaged' stocks, but as long as samples have been aged.) This is the most biologically dangerous harvesting approach possible (yet one [DFO's] Science Branch has never gone so far as to oppose (A.Finlayson 1994:64).

For Rice and DFO, it was a politically intractable research question. Finleyson, in Fishing for Truth, took no issue with Rice on this point. Neis relied on local recollection without probing the ecological impacts of the new technology.

\section{Conclusion}

I suggest that the collapse of the northern cod would not have been adequately foretold or comprehended by a political ecology whose governing and guiding principles are drawn from political economy. A significant factor in the collapse was the scientific misreading of the actual state of the resource, and at the heart of this error was the nexus of technology and environment. The Canadian offshore replacements for the foreign deepsea fleets became, in the early 1980s, very efficient in finding and catching cod. The fish themselves apparently obliged by concentrating as their numbers thinned. Inshore technology developed as well, first at the urging of provincial and federal officials, then through economic necessity in the face of declining yields. The largely unexamined effects of technological change in this sector may have contributed to the collapse. Capital did, to be sure, penetrate through all sectors of the fishery. But at times it had a relatively benign face: to increase the range and season of the inshore fishery, to prolong the jobs of plant workers, to position Newfoundland to exploit (with hindsight, to destroy) the offshore waters vacated by the foreign factory freezer trawlers.

Although it might be worthwhile to direct a political ecology, as Michael Painter does, to study "the social and economic processes that underlie environmental degradation and underdevelopment...dealing explicitly with the fact that both processes occur in complex societies joined to one another by a global economy and ecology, and characterized by social classes with fundamentally divergent interests" (1995:9), I fear that this might result in what one of my colleagues calls "a paralysis by analysis." I would rather start with real people doing real things. In the case of the northern cod, many of the real things were done for quite reasonable reasons, resulting in an ongoing disaster. This is rather bothersome, as it means that we do not, at the outset, have the answers. 


\section{References}

CAFSAC

1989. Advice for 1989 on the management of cod in divisions 2J3KL. Canadian Atlantic Fisheries Scientific Advisory Committee Advisory Document 89/1.

Davis, Anthony, and Victor Thiessen

1986. Making Sense of Dollars: Income Distribution among Atlantic Canadian Fishermen and Public Policy. Marine Policy (July):201-214.

Felt, Lawrence F.

1994. Two Tales of a Fish: The Social Construction of Indigenous Knowledge among Atlantic Canadian Salmon Fishers. In Folk Management in the World's Fisheries. Christopher L. Dyer and James R. McGoodwin, editors. Niwot, CO: University Press of Colorado, pp. 251-286.

Felt, Lawrence F., and Barbara Neis

1996. A Bridge over Troubling Waters: Social Science and Interdisciplinarity in Sustainable Fisheries Management. MS on file with author.

Finlayson, Alan Christopher

1994. Fishing for Truth: A Sociological Analysis of Northern Cod Stock Assessments from 1977-1990. Social and Economic Papers No. 52, Institute of Social and Economic Research. St. John's: Memorial University of Newfoundland.

Garrod, D.J.

1988. North Atlantic Cod: Fisheries and Management to 1986. In Fish Population Dynamics, 2nd. ed. J.A. Gulland, editor. Chichester, UK: John Wiley \& Sons, pp. 185-218.

Hilborn Ray, and Carl J. Walters

1992. Quantitative Fisheries Stock Assessment: Choice, Dynamics and Uncertainty. New York: Chapman and Hall.

Hutchings, Jeffery A., and Ransom A. Myers

1994. What Can Be Learned from the Collapse of a Renewable Resource? Atlantic Cod, Gadus morhua, of Newfoundland and Labrador. Canadian Journal of Fisheries and Aquatic Sciences 51:2126-2146.

Hutchings, Jeffery A., Carl Walters, and Richard Haedrich

1997. Is Scientific Inquiry Incompatible with Government Information Control? Canadian Journal of Fisheries and Aquatic Sciences 54:1198-1210.

Innis, Harold A.

1930. The Fur Trade in Canada: An Introduction to Canadian Economic History. Toronto: University of Toronto Press [1956 edition].

1940. The Cod Fisheries: The History of an International Economy. Toronto: University of Toronto Press [1978 edition].

Kurlansky, Mark

1997. Cod: A Biography of the Fish that Changed the World. New York: Walker and Company.

Lear, W.H., and L.S. Parsons

1993. History and Management of the Fishery for Northern Cod in NAFO Divisions 2J, 3K, and 3L. In Perspectives on Canadian Marine Fisheries Management. L.S. Parsons and W.H. Lear, editors. Canadian Bulletin of Fisheries and Aquatic Sciences No. 226, pp. 55-90. 
Maguire, Jean-Jacques, Barbara Neis, and Peter R. Sinclair

1995. What are we Managing Anyway? The Need for an Interdisciplinary Approach to Managing Fisheries Ecosystems. Dalhousie Law Journal 18(1):141-153.

Matthews, Ralph, and John Phyne

1988. Regulating the Newfoundland Inshore Fishery: Traditional Values Versus State Control in the Regulation of a Common Property Resource. Journal of Canadian Studies 23(1/2): 158-176.

Matthews, David Ralph

1993. Controlling Common Property: Regulating Canada's East Coast Fishery. Toronto: University of Toronto Press.

McNally, David

1981. Staple Theory as Commodity Fetishism: Marx, Innis and Canadian Political Economy. Studies in Political Economy 6:35-63.

Neis, Barbara 1992. Fishers' Ecological Knowledge and Stock Assessment in Newfoundland. Newfoundland Studies 8(2):155-178.

Painter, Michael

1995. Introduction: Anthropological Perspectives on Environmental Destruction. In The Social Causes of Environmental Destruction in Latin America. Michael Painter and William H. Durham, editors. Ann Arbor: University of Michigan Press, pp. 1-21.

Pisani, Donald J.

1992. To Reclaim a Divided West: Water, Law, and Public Policy, 1848-1902. Albuquerque: University of New Mexico Press.

Rogers, Raymond A.

1995. The Oceans are Emptying: Fish Wars and Sustainability. Montréal: Black Rose Books.

Schmink, Marianne, and Charles H. Wood

1987. The 'Political Ecology' of Amazonia. In Lands at Risk in the Third World: Local-Level Perspectives. Peter D. Little and Michael M. Horowitz, with A. Endre Nyerges, editors. Boulder, CO: Westview Press, pp. 38-57.

Sinclair, Peter R.

1985. From Traps to Draggers: Domestic Commodity Production in Northwest Newfoundland, 1850-1982. Social and Economic Papers No. 31, Institute of Social and Economic Research. St. John's: Memorial University of Newfoundland.

Steele, D.H., R. Andersen, and J.M. Green

1992. The Managed Commercial Annihilation of Northern Cod. Newfoundland Studies 8(1):34-68.

Thiessen, Victor,and Anthony Davis

1986. Update: A Further Note to Making Sense of Dollars. Marine Policy (October):310-314.

Tversky, Amos, and Daniel Kahneman

1982. Judgment under Uncertainty: Heuristics and Biases. In Judgment under Uncertainty: Heuristics and Biases. Daniel Kahneman, Paul Slovic, and Amos Tversky, editors. Cambridge: Cambridge University Press, pp. 3-20.

Vayda, Andrew P.

1983. Progressive Contextualization: Methods for Research in Human Ecology. Human Ecology 11(3):265-281. 
Vayda, Andrew P.

1988. Actions and Consequences as Objects of Explanation in Human Ecology. Environment, Technology, and Society 51:2-7.

Walters, Carl, and Jean-Jacques Maguire

1996. Lessons for Stock Assessment from the Northern Cod Collapse. Reviews in Fish Biology and Fisheries 6:125-137.

\section{Abstract:}

Social scientists in Atlantic Canada developed an incisive political economy of the region's fisheries in the 1970s and 1980s and forged a sharp critique of Canadian fisheries policies. Meanwhile, fisheries scientists generated a series of stock assessments which substantially overestimated cod populations. After the collapse of the stocks in 1992, a number of reflective postmortems have addressed the role of the social and natural sciences in this resource failure. The present paper will attempt to construct a "political ecology" of the crisis from this corpus, one which does not, a priori, privilege industrial capitalism over cod ecology.

Key Words: fisheries, cultural ecology, political economy, technology, Atlantic Canada, cod.

\section{Resumé:}

La Dernière Morue du Norde Résumé Les spécialistes des sciences humaines dans le Canada Atlantique ont développé une économie politique tranchante des pêcheries de la région dans les années 1970 et les années 1980 et ont forgées une critique vive des politiques de pêcheries Canadiennes. Pendant ce temps, des hommes de science de pêcheries produisaient une série d'évaluations des stocks qui a surestimé d'une façon importante les populations de morue. Après l'effondrement des stocks en 1992, un certain nombre des postmortems réfléchissants ont adressé le rôle des sciences sociales et naturelles dans cet échec dans l'aménagement de ressources. L'article actuel essaiera de construire une "écologie politique" de la crise à partir de ce corpus, une qui ne privilège pas, à priori, le capitalisme industriel sur l'écologie de morue.

Les mots clé: les pêcheries, écologie culturelle, économie politique, technologie, Canada Atlantique.

\section{Resumen:}

Científcos sociales del Atlntico de Canad han desarrollado un anlisis incisivo de la economa política de la pesca de la regin durante 1970 y 1980 y han hecho una crítica aguda de las políticas de pesca. Entretanto, cientficos marinos han generado una serie de asesoras sobre los poblaciones de bacalao que ha sobre estimado sus poblaciones. Despus del colapso de poblaciones de bacalao en 1992, una cantidad de necropsias del la crisis del bacalao han analizado el papel de las ciencias sociales y naturales en este fallo del recurso. Usando esta literatura, este artículo tratará de construir una ecologa poltica de esta crisis, una que no anteponga una explicacin industrial capitalista, a priori, antes de la ecologa de bacalao.

Palabras claves: pesca, ecologa cultural, economa poltica, tecnologa, Atlntico del Canad 